\title{
Creativitate lingVistică în DenUmirea UNOR PREPARATE CULINARE TRADIT,IONALE DE FRUPT/DULCE SAU DE POST ADAPTATE LA SPAT, IUL URBAN MOLDOVENESC
}

\author{
LUMinița Drugă \\ Universitatea „Vasile Alecsandri” din Bacău, România \\ Linguistic creativity in naming traditional dishes for fasting \\ vs. non-fasting days, adapted to Moldavian urban space
}

\begin{abstract}
The desire to counteract the latest Western or Asian culinary trends in Romanian cuisine paralleled by the urge to cater for a variety of tastes in accordance with seasonal and religious calendars have definitely impacted on the gastronomic specialties of restaurants in the region of Moldavia, which enjoy a well-established or newly earned reputation for preserving tradition as regards the ingredients and methods used in preparing their dishes. By observing that, in addition to ensuring culinary variety through unique dishes and old favourites, restaurant owners or their advertisers also explore the linguistic means of expression in the names of dishes and drinks, we aim to examine an inventory of ritual/festive vs. daily meals to show how names of dishes for fasting or non-fasting days are turned from mere identifying labels into potent onomastic devices with stylistic effects and persuasive powers on the targeted consumers.
\end{abstract}

Keywords: linguistic creativity, Moldavian cuisine, dish name, fasting dish, nonfasting dish.

\section{Introducere}

Discursul gastronomic oferă indicii valoroase asupra identității naționale, mai ales astăzi, având în vedere explozia de influențe în contextul globalizării, proces la care este supus și consumatorul român, după o lungă perioadă de abstinență și sărăcie alimentară din perioada comunistă. În cadrul acestui tip de discurs (rețete culinare, emisiuni cu caracter gastronomic), cel al meniurilor ocupă un loc aparte. Dorința de a contracara recent intratele mode culinare asiatice și occidentale din bucătăria românească, dublată de necesitatea de a oferi o gamă cât mai largă de produse, în concordanță cu calendarul religios și cel sezonier, a avut un impact simțitor asupra specialităților gastronomice din meniurile restaurantelor din regiunea istorică a Moldovei, care se bucură de o bună reputație în păstrarea tradiției, atât în privința ingredientelor, cât și a rețetelor. Pe lângă preocuparea de a asigura o varietate culinară prin oferirea spre consum a unor feluri de mâncare unice (gen specialitatea casei) alături de clasicele bucate moldovenești, deținătorii de restaurante sau specialiștii în publicitate, cu care se 
colaborează, exploatează mijloacele lingvistice care asigură variaţie stilistică în denumirile de mâncăruri și băuturi. Pornind de la această constatare, ne propunem să analizăm un corpus de denumiri ale unor preparate cotidiene sau festive, de frupt şi de post, astfel încât să reliefăm modul în care acestea sunt transformate în elemente de identificare care pot căpăta forță persuasivă în relația cu consumatorii. Numele felurilor de mâncare, descrierea lor sumară în cadrul meniului, ilustrând elementul național sau care aparține altor popoare și culturi reprezintă una dintre strategiile diverse, orientate către receptor, cu scopul de a-l atrage, a-l seduce și a-i incita curiozitatea papilelor gustative. Analizând discursul meniului dintr-un restaurant, dorim să demonstrăm faptul că acest mecanism de folosire a numelor preparatelor culinare și descrierea lor uzitând de norma lingvistică specifică zonei este nu numai o modalitate de marcare a identității în raport cu alteritatea naţională, ci se încearcă, în același timp, și stabilirea unei comuniuni de ordin fatic între colocutori. Cadrul teoretic al demersului nostru este tributar lui Dumistrăcel (2006) și Dupuy (2009).

\section{Meniul ca obiect}

Meniul este poate cea mai importantă componentă a identității de marcă a unui restaurant. Jean Philippe Dupuy (2009a) consideră meniul un obiect „prefigurativ”, a cărui primă funcție este de a permite celui care-l atinge, vede, să-și reprezinte o situație, un proces ce va să vină și astfel dezvoltă o serie de așteptări clientului, încă de la momentul contactului fizic cu acesta. Îl citești, îl răsfoiești și astfel meniul apare înzestrat cu un potențial comunicațional și funcție ideologică, adică te determină să crezi ceva sau în ceva (http://www.mei-info.com/wp-content/uploads/2014/02/MEI_3031_07. pdf). Analiza meniului presupune, de asemenea, studiul practicilor și funcțiilor sale. Autorul menționat (2009a: 118) realizează o clasificare a meniurilor, ținând cont de funcția pe care acestea o îndeplinesc, și stabilește două tipuri. În primul rând, avem un meniu „prothétique”, pe care l-am considerat fix, planificat, adică cel pe care îl regăsim pe masa unui banchet, a unei ocazii speciale, reuniuni de familie şi prin intermediul căruia gazda prezintă musafirilor felurile de mâncare pe care le vor regăsi pe masă și, în al doilea rând, un alt tip de meniu, denumit „procritique”, la alegere, diversificat, adică „obiectul” care îi permite clientului unui restaurant, han etc. să opteze pentru un fel de mâncare în defavoarea altuia. Pe lângă cele două tipuri de meniu stabilite de Dupuy, de menționat este și meniul „à la carte”. Între aceste tipuri de meniuri există, desigur, mai multe diferențe. Prima se referă la faptul că în timp ce meniul prothétique este un accesoriu marcă a eleganței și rafinamentului unei mese organizate, cel de-al doilea este proprietatea unui restaurant, un element de identificare al acestuia, care contribuie într-o mare măsură la crearea unui prestigiu. Însă, cea mai mare dintre diferențe pornește de la funcția pe care o îndeplinesc diversele tipuri de meniuri. Dacă meniul unui banchet, al unei mese organizate are în principal un rol pur decorativ, care evidențiază imaginea socială a gazdei, reafirmând astfel bucuria de a împărți bucatele cu ceilalți și în acest caz obiectul, cu aspectul său, forma de organizare, mai mult decât conținutul său verbal, este important, în cazul meniului de la restaurant (clasic sau à la carte), principala 
funcție este cea a facilitării alegerii și astfel devine terenul de reprezentare care îi va permite clientului să-şi imagineze spectacolul culinar pe care îl așteaptă. Altfel spus, acest tip de meniu este un triumf al individualității.

Meniul, lecturat ca simplu text, este și „obiect” al unei „retorici” alimentare (Dupuy 2009b:20) şi de aceea şi este conceput uneori ca un text menit să placă și să convingă. Dincolo de acest fapt, însă, din discursul meniului transpar o serie de urme mnemonice care sunt izvorâte din consumurile și experiențele senzoriale, lecțiile sociale anterioare care permit să ajungi la gustul alimentului. Meniul apare ca un „ambreiaj vizual al gustului”, care intră în redundanță cu alte semne și împreună vor reuși să compună teatrul gastronomic la care concură și organizarea spațiului, decorarea și aranjarea mesei, calitatea serviciilor.

Discursul meniurilor se subsumează discursului publicitar, un limbaj cu o personalitate proprie, aparte, pe care Stelian Dumistrăcel (2006: 64) îl deosebește de limbajul publicistic. Așa cum apreciază autorul, toate funcțiile limbajului publicitar pot fi regăsite în discursul meniurilor, cu precizarea că aici, rolul predominant revine funcției fatice, care are un rol evident în strategia de construire a unei conexiuni la nivel psihologic între emițător și receptor, conexiune menită să inițieze și să mențină comunicarea cu scopul persuadării clientului.

Meniul, cartea de identitate a unei unităţi cu profil alimentar (han, restaurant, pensiune) a trecut de-a lungul timpului, din punctul de vedere al formei, prin diferite transformări, de la o simplă listă, în care sunt înșiruite feluri de mâncare, la adevărate „cărticele” cu coperte legate în piele, cu decorațiuni și imagini îmbietoare. Simpla listă a felurilor de mâncare poate fi interpretată ca o mostră de cultură și civilizație, sursă de informare pluridisciplinară, o splendidă pagină de istorie gastronomică, o întreagă lume cu gusturile ei, o oglindă a stratificării sociale a timpului, un document de epocă (vezi Cazacu, Matei 1997: 7). După modelul turcesc al caravanseraiurilor, apar și în țările române hanuri și ratoșe ${ }^{1}$, dintre care unele devin celebre (Hanul lui Manuc în Muntenia, Hanul Ancuței în Moldova). La sfârşitul secolului al XIX-lea, după Războiul de Independență, locul acestora este luat de restaurantele care își fac apariția în societatea românească și, odată cu ele, inclusiv gastronomia românească cunoaște o diversificare pe care o va pierde în timpul celor 50 de ani cât va dura comunismul, perioada cea mai neagră a gastronomiei românești. La fel ca acum mai bine de un secol, după momentul 1989, societatea românească se confruntă cu acelaşi fenomen al unei explozii de gusturi, după o jumătate de veac în care grătarul cu cartofii pai era preparatul de lux, atât al restaurantelor, cât și al meselor festive din viața cetățeanului de rând. Însă, ca mai toate modelele, și furia modei culinare care promitea preparate exotice este înlocuită de „dorul” după tradițional, pe care puzderie de restaurante îl promit prin denumiri atrăgătoare, prin meniuri îmbietoare. Dar, într-o țară cu o populație predominant ortodoxă, în care există, conform calendarului circa 200 de zile de post de-a lungul anului, cererea impune oferta astfel încât moda gastro-

1 Han așezat la o șosea principală [Var.: rátoș s. n.] - din ucr. ratuś (cf. DEXI, s.v.). 
nomică a momentului este îmbogățită cu preparate vegetariene, de post și, din ce în ce mai des, chiar și vegane.

\section{Meniul „Casa Moldoveană” - studiu de caz}

Una dintre noile strategii de marketing pentru atragerea clienților ivită pe piață și-a îndreptat atenția asupra componentei lingvistice a meniurilor. În cele ce urmează, propunem o analiză asupra unui meniu al unei pensiuni/restaurant și anume Casa Moldoveană din Piatra-Neamț (notată în continuare CM), care, după cum transmite prin nume, încearcă să-și atragă clientela, mai întâi prin trimiterea la noțiuni ca familie, casă, un loc primitor și mai apoi, prin apelul la bunul renume al tradiției culinare moldovenești. Așa cum aflăm din pagina de prezentare a pensiunii, $C M$ este situată pe DN 15D la intrarea în Piatra-Neamț dinspre municipiul Roman și promite clienților „un fragment de liniște uitat de tumultul orașului [...] O contopire amețitoare de modern și rustic, o amprentă a bunului gust și personalității. Casa Moldoveană rămâne borna de intrare în lumea ospitalității moldovenești” (http://www.pensiunipiatraneamt.ro/menu/). Propunem în continuare o analiză strict lingvistică a textului meniului și nu a bucătăriei pe care acesta o promovează și oferă. Menționăm, de asemenea, că textul meniului este din arhiva personală, el neputând fi accesat de pe pagina de site. Considerăm că acest tip de analiză furnizează cercetătorului interesat, din diverse domenii, atât informații despre specificul local, cât și despre moda culinară a momentului. Arsenalul de mijloace lingvistice (fonetice, morfologice, lexicale, stilistice), mai mult sau mai puțin bine folosite, după cum vom vedea, din textul meniului de la $C M$, vizează persuadarea clientului în privința bucătăriei, după cum suntem avertizați „aici totul poate avea gustul perfecțiunii și clipele își capătă sens” (http://www.pensiunipiatraneamt.ro/menu/).

Meniul, ca obiect în sine, prezintă puține variații din punctul de vedere al formei și, împreună cu textul verbal, materialul din care este confecționat (hârtie, piele, carton) orientează percepțiile asupra adevăratului gust al lucrurilor (Dupuy 2009a: 111). Cel mai adesea, meniul se înfățișează ca o foaie sau ansamblu de foi rectangulare de diverse mărimi (tip A3, A4, A5), iar din acest punct de vedere meniul în discuție nu se distinge prin nimic original, prezentându-se clientului ca un ansamblu de foi tip A4 prinse la un loc. Structura grafică și modelele tipografice ale textului pot participa și ele la realizarea unei imagini, însă acesta pare un aspect pe care autorul meniului studiat nu pare să-l fi avut în atenție, de aceea meniul de la $C M$ este redactat cu majuscule de culoare neagră, Times New Roman, cu litere de dimensiuni aleatorii, fără respectarea vreunei reguli. Denumirea restaurantului și prezentarea ar fi cerut, probabil, și folosirea unui scris de mână tip Vivaldi, Lucida Handwriting etc.

Din punct de vedere compozițional, meniul de la CM păstrează forma de organizare a preparatelor din meniurile clasice, adică mâncăruri de frupt și mâncăruri de post, cu pagină dedicată aperitivelor, denumite aici „pregăteli de-nceput”, apoi supe și ciorbe, care aici devin „fierturi acre și dulci”, urmate de feluri de mâncare așezate în funcție de materia primă (vită, pui, porc, pește) „găteli din mușchiuleț de jițăl”, „găteli din pui”, 
„găteli din pește”, „găteli din godac”, preparate la grătar denumite „dichisăli jăruite”, și bineînțeles, nelipsita pagină cu specialitatea bucătarului („dichisălile bucătarului”). Mâncarea de post „găteli de post” și salatele („foi de grădină cu acreală, untdelemn și cu câte alti cele") întregesc oferta împreună cu cafeaua din categoria preparatelor cu caracter terapeutic „fierturi vătămătoare”.

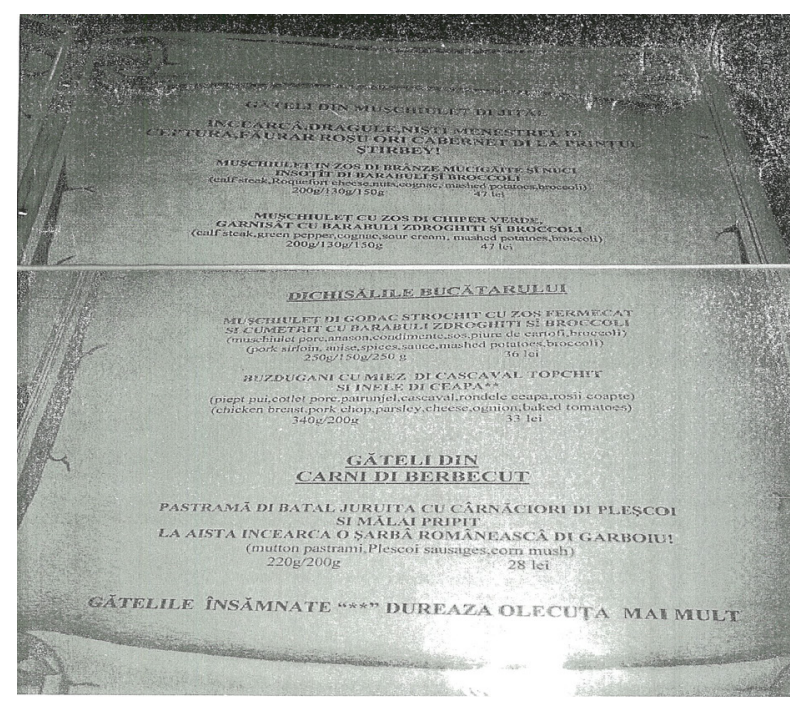

Figura 1: Pagină meniu Casa Moldoveană (arhiva personală)

\section{III.1. „Lingvistica meniului”}

Meniul unui restaurant este gândit și prin forma sa de prezentare, prin text, în relație cu clientul, cu atmosfera și contextul pe care le propune, iar textul pe care îl supunem analizei demonstrează că s-a avut în vedere această componentă. Având în vedere caracterul textului, menționăm că am realizat transcrierea fonetică pentru fenomenele specfice Moldovei, necunoscute celoralte regiuni. În rest, am optat pentru transcrierea literală, conform originalului.

\section{III.1.1. Nivelul fonetic}

Unul dintre nivelurile lingvistice intens exploatate în textul meniului de la $C M$ este nivelul fonetic.

III.1.1.1. Un fenomen fonetic specific zonei Moldovei îl reprezintă închiderea lui e la i mai ales în poziție finală, iar meniul de la CM înregistrează multiple fonetisme de tipul: barabuli/[ba-ra-bú-li] „îndesati”/ [în-de-sá-ti], „,cu di tăti”/[di] [tắ-ti], „tocanâ di iepure”/[ to-cá-nî], „fasoli” /[fa-só-li], „barabule ferti”/ [ba-ra-bú-li], „rondeli di ananas”, „barabuli coapti”/[koáp-ti], „barabuli zdroghiti”, [ba-ra-bú-li] [zdro- gí-ti], „cari” [ká-ri].

III.1.1.2. Palatalizarea, adică modificare fonetică prin care o consoană oarecare 
devine palatală, este și ea înregistrată în textul meniului de la $C M$ în diverse contexte fonetice:

III.1.1.2.1. palatalizarea consoanei b este înregistrată în exemple ca: „ceapă zdroghită” /[čápă] [zdro- ǵí-tî], „,barabuli zdroghiti”/ [ba-ra-bú-li] [zdro- gí-ti];

III.1.1.2.2. Palatalizarea consoanei $\mathbf{p}$ este bine reprezentată în textul meniului în exemple precum: „chicior de jițîcă”/ [র́í-čór][ji-țî-kî], „brânze italienești topchite”/

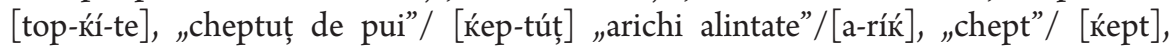
„chept umplut" / ['́ept], „bătutele din chept de pui”, „strochit cu zos”/[stro-ḱít] „,chicioarele de pui”/[ḱi-čoá-re-le], „chetre calde”, ['́é-tre] „cafea topchită”/[top-ḱí-tă] „zos de chiper verde” / [ḱi-pér] „cafea mică chetroasă”/ [ḱe-troá-să];

III.1.1.2.3. Palatalizarea labiodentalei v: „jițăl”/[žițăl] ,jiț̦el”/[ žițél], „jițîcă”/[ žițîkă], ,jinuț"/[žinúț;

III.1.1.2.4. Palatalizarea labiodentalei $\mathbf{f}$ este întâlnită numai în cazul lexemului „fierbinte”: „ciocolată șerbinti” / [ĉer-bin-ti], „„cu apă șerbinti”/”[ĉer-bin-ti], „,mămăligâ șerbinti”/[çer-bin-ti]]. Însă, necunoașterea normei lingvistice este la ea acasă în textul meniului de la $C M$ și este demonstrată, printre altele, de absența unui fenomen fonetic specific arealului lingvistic nordic-moldovenesc și anume a palatalizării labiodentalei f în unele situații, ca de exemplu „barabule ferti”, „șunculițâ fiartă”.

III.1.1.3. Velarizarea. Prin schimbarea locului de articulație, vocalele prepalatale $\boldsymbol{e}(-e-,-e$ - din diftongul $e a)$ și $i$, precedate de anumite consoane, devin vocale velare: $\breve{a}(-\breve{a}-)$ și $\hat{\imath}$. Datorită rostirii dure, velare, respectiv muiate, prepalatale, a consoanelor precedente, are loc o schimbare a locului de articulație și, implicit, a timbrului vocalelor respective. Fenomenul a avut loc în diferite graiuri, în perioade diferite și în condiții fonetice specifice anumitor categorii de consoane. În momentul apariției textelor vechi românești, efectele acestor schimbări în graiuri se produseseră, astfel încât în texte se reflectă în mare măsură un amestec al formelor velarizate și nevelarizate, amestec care a devenit normă până astăzi în limba literară (Arvinte 1995: 56), iar fenomenul joacă un rol important în definirea normei literare românești, atât în epoca veche, cât și în cea modernă și contemporană.

III.1.1.3.1.Velarizarea prin $\mathbf{s}$ este prezentă în meniul analizat în numeroase ocurențe: „gătelile însămnate”/[ însămnate] ”, „tocmagi di să cheamă”/[să], „di pi oasâ"/[ua-sî], „dichisălile bucătarului"/[di-ḱi-sắ-li-le], „să face când și când”/[să].

III.1.1.3.2.Velarizarea prin ț este ilustrată în textul supus analizei în exemple precum: „bețî̀”/[be-țîv], ,jiłtîică”/[žițîkă],], „şunculițâ”/[ŝun-ku-li-țî], „sărmăluțâ”/[sărmă-lu-țî̀], și „sălățâcă”/[ [să-lă-țî-kî̀].

III.1.1.3.3. Velarizarea prin $\mathbf{z}$ este înregistrată în meniul $C M$ în numeroase ocurențe ale cuvântului „zeamă”: „zamă de buruieni”/[zá-mă], „zamă ardelenească”, „zamă țărănească”, ,zamă de găină”, „zamă de fasole”, „zamă ca la Rădăuț, , „zamă dulce de chicior de jîțîcă”.

III.1.1.3.4. Velarizarea prin ș este și ea prezentă într-o serie de ocurențe: „̧̧ı̂ pere”/

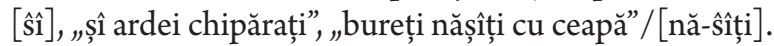

III.1.1.4. Apocopa, „cădere a unui sunet, a unei silabe sau a unui grup de silabe 
de la sfârșitul unui cuvânt” (<fr. apocope, lat. apocopa, DTL, s.v.), este înregistrată în „cârnăciori di la tăietu' porcului”.

III.1.1.5. Haplologia, „suprimare prin disimilaţie totală a unei silabe identice sau asemănătoare cu o silabă din același cuvânt sau din cuvinte învecinate" (<fr. haplologie), este ilustrată în meniul în discuție prin lexemul „mămăligă” care este înregistrat în varianta „măligă”: „șî c-oleacă di măligâ”/ [mă-lí-gî1], „brânză cu smântână logodită cu măliguță”/ [mă-li-gú-ță].

III.1.1.6. Metateza, adică schimbarea ordinii unor sunete, este un alt fenomen fonetic pe care-l regăsim în textul studiat și care se dorește a fi marcă identitară. Astfel, lexemul vârste cu sensul „dungă sau bandă de altă culoare într-o țesătură” este înregistrat în varianta cu metateză „vrâste nemțești”.

III.1.1.7. Alte fenomene fonetice/ ortografice

$\mathrm{O}$ altă trăsătură specifică variantei literare moldovenești, nordice, se referă la prezența formelor etimologice în lexeme de tipul „câne, pâne, mâne”. Cum autorul textului nu pare să cunoască această trăsătură distinctivă a normei lingvistice nordice, lexemul diminutival „pâiniță” este înregistrat numai în varianta fonetică cu i epentetic, trăsătură specifică normei sudice: „pâiniță cu pătlăgele”, „pâiniță cu pește”, nu cu î/âa așa cum ar fi impus norma lingvistică.

Lipsa de consecvență apare și în scrierea unor cuvinte care au aceleași vecinătăți „di jițăl”, „de jițel”, „de pui”, „de godac”, „di la tăietu”, „ș̂, /,și”.

De asemenea, două variante grafice ale aceluiași cuvânt atrag atenția în corpusul studiat. Este vorba despre „zos” și „sos”, din câte se poate deduce, ambele cu același referent, cu observația că varianta fonetică „zos” nu are nicio explicație logică: „zos cafeniu cu bureți”, cu „zos de chiper”, „în zos de brânze”. „Exploatarea” nivelului fonetic al limbii române are ca scop evidențierea caracterului moldovenesc, tradițional al bucătăriei.

Însă, nu numai nivelul fonetic „suferă” în acest text. Nici regulile ortografiei actuale nu îi sunt prea bine cunoscute autorului meniului de la $C M$ având în vedere degringolada ortografică a textului. Folosirea în redactarea textului a literelor â și î este la voia întâmplării, astfel încât în numeroase situații regăsim â din a în poziție finală, contrar normelor ortografice actuale: „acrâ”, „meritâ”, „măligâ”, „tocanâ”, „grădinâ”, „nucâ”, „șunculițâ”, „fiartâ”.

Chiar dacă unele dintre trăsăturile fonetice proprii variantei literare nordice (Gheție 1974: 237) se regăsesc în paginile meniului de la CM, utilizarea lor este inconsecventă și demonstrează, din punct de vedere lingvistic, științific, amatorismul. Râmâne evidentă intenția ludică, ca strategie de persuadare și atragere a consumatorului.

\section{III.1.2. Nivelul morfosintactic}

III.1.2.1. La nivel morfologic, se poate observa cu ușurință prezența în text a unor substantive al căror plural nu este conform normei literare actuale în e, acestea fiind înregistrate în varianta cu i: „potcoavi”, „pătlăgeli”, „barabuli”, „lapti”, „jumeri”, dar și în cea cu e: „barabule” etc. 
III.1.2.2. Substantivul „chinez” prezintă în text forma de plural „chineji” specifică stilului colocvial, popular.

III.1.2.3. Pronumele relativ „care” este înregistrat în textul meniului de la $C M$ numai în varianta cu i final: „cari”: „,cu vreun jinuț cari nu-ț faci cinsti”, ,ferturi vătămătoare de sorghit în odaia di oaspeți și cari alungă somnu...”

III.1.2.4. Cu aceeași intenție ludică se folosește și pluralul „brânze” în structura „zos de brânze”.

III.1.2.5. În privința organizării sintactice a textului meniului, acesta îi prezintă clientului de la enunțuri cât se poate de simple, eliptice de predicat, asemănătoare unei liste: „tocinei rumeniți”, ,tochitură moldovinească”, ,ciocolată șerbinti”, „tocmagi bolognesi”, „păstrăv la hârzob” la denumiri care se constituie în adevărate fraze inserate în structuri sintactice cu ajutorul prepozițiilor și al conjuncțiilor, ceea ce presupune existența unor raporturi de subordonare construite și ele cu evidentă intenție amuzantă: „Somon în ogheal di aluat. Aista durează di ți să lungesc urechile di foame ...adicătelea vro 45 di minuti; „,șunculițî di casă fiartă-n moare acră și pălită cu usturoi, cafea di ceea de-ți sare pălăria”.

III.1.3. Nivelul lexical este din plin exploatat ca manieră de ilustrare a caracterului moldovenesc al bucătăriei de la $C M$. Astfel, textul abundă în regionalisme și cuvinte populare: „barabuli”/,barabule” pentru „,cartof”, „,curechi” pentru varză, „pătlăgele” cu sensul „roșii, „cucuruz”, varianta moldovenească a lui „porumb”, ,godac”, termen popular pentru „purceluș de un an”, „pălit” cu sensul „lovit”, „gogoloaie din cașcaval pentru „crochete”, „tocmagi”, variantă nordică pentru „„ăiței”, „oghial” cu sensul „plapumă” etc.

O altă strategie argumentativă de care uzează gastronomia modernă comercială și care are la bază o axiologie care implică în același timp produsul, bucătăria, bucătarul, clientul, este cea a organizării în jurul unor valori esențiale ale lumii contemporane intens mediatizate: tinerețe și suplețe, promise în diferite circumstanțe (vezi Dupuy 2009b: 18). Interesantă din perpsectiva pragmaticii comunicării este prezența „diminutivelor manipulatoare” în meniuri (vezi Dumistrăcel 2008). Textul analizat nu face excepție. Carnea de vită este de „jițâaca”, cea de porc de „godac” (purceluș de un an), se servește numai „mușchiuleț”, creierul este dosit prin „oușoare”, „arichile” sunt alintate și ele cu „ouşoare”, culcuşul este pentru „cheptuț de pui”, marinata este „iuțâcă”. De asemenea, suntem îmbiați cu „mititei”, ,ficăței”, „pâiniț̆ă”, „șunculițâ”, , „ârnăciori”, „pere acrișoare”, „,sărmăluți”, „,sălățâcă”, „, „hept de cocoșel” etc. Sunt înregistrate însă și lexeme cu valoare augmentativă, cu un evident sens depreciativ: „salata ca la bulgăroi”.

Atât componenta tradițională, cât și cea cosmopolită a meniurilor se constituie în parte a strategiei de promovare a ofertei restaurantelor, care sunt, evident, manifestări ale faticului la nivelul comunicării de tip comercial (vezi Drugă și Savin, 2009:112). Unele dintre preparatele prezentate în paginile meniului incită nu numai papilele gustative, ci și intelectul clientului care este pus să ghicească, folosindu-și experiența lingvistică, idiomatică expresivă și culinară în același timp, pentru a înțelege ce comandă. „Insistența asupra mărcii tradițional este, evident, parte din ansamblul unei strategii 
fatice de atragere a clientului, deci, de menținere a unui contact psihologic permanent cu potențialul cumpărător care prețuiește valorile tradiționale” (Savin 2012: 119). Feluri de mâncare cosmopolite care încep să caracterizeze bucătăria românească actuală sunt deghizate într-o haină lexicală așa-zis moldovenească. Gastronomia românească contemporană s-a îmbogățit, după anul 1989, și cu varietăți ichtiologice, ca de exemplu somonul. Sandvișurile cu somon afumat devin la $C M$ „Pâiniță cu pește din cela roz fumegăit”. Cu greu ar putea înțelege unii clienți că un lexem precum „fumegăit”, are sensul „afumat”. „Pâinița cu pătlăgele și busuioc” reprezină varianta moldovenizată de la CM pentru „bruschetele italienești cu roșii”, iar crema de brânză este transformată în „Frecătură de brânză cu foi de cimbru”. „Aceeași valoare de marcă, dar de această dată situată întru cu totul altă zonă, o are și componenta cosmopolită a meniului, în care evidenta origine străină a unor feluri de mâncare atrage cumpărătorul deschis către inedit, nou, modă” (Savin 2012: 119). „Deliciul” lingvistic al acestui meniu îl reprezintă tocmai asocierile lexicale inedite și amuzante. Pe lângă regionalul „tocmagi” apar toponime sonore și binecunoscute în gastronomia mondială precum „Carbonara”, „Bolognesi”, „Valdostana” într-un „pur” cocktail lexical globalizat.

\section{IV. „Axiologia” meniului}

Dupuy (2009b: 10) apreciază că retorica meniului se exprimă printr-o strategie argumentativă care se sprijină pe o axiologie de bază fundamentată pe un sistem de valori care implică în același timp produsul, bucătăria, clientul/meseanul, iar partajarea tuturor acestor valori reprezintă o condiție necesară. Astfel, rolul meniului este acela de a pune în scenă, prin intermediul cuvintelor, un sistem de valori larg împărtășit de comeseni. Căutarea autenticităţii presupune și selectarea produselor de calitate.

Unele dintre preparatele din meniul analizat au o denumire foarte lungă prin care se dorește prezentarea nu numai a produsului, ci și a bucătăriei, a procesului tehnologic, a ingredientelor folosite, toate drept marcă a calității: „Șunculițâ di casâ, fiartă-n moare acră și pălită cu usturoi”, „Salată cu brânză de capră ținută-n poloboc cu sare” (brânza sau capra!!! ne întrebăm având în vedere ambiguitatea exprimării), „Grădină descântată pi chetre caldi”, „Bulz din malai cu clop de la stână”, denumiri care fac apel nu numai la competența lingvistică a clientului, dar și la cultura, rafinamentul și simțul estetic al acestuia, care trebuie să înțeleagă, dincolo de acest spectacol lingvistic, valoarea bucătăriei oferite, savoir-faire-ul.

Denumirile mai lungi ale unora dintre felurile de mâncare din corpusul analizat se constituie într-o poveste cu personaje principale și adjuvante, adică restul legumelor și ingredientelor folosite. Astfel, iepurele fricos este personajul unei tocănițe la care beneficiem și de aprecieri, neobişnuite pentru un asemenea tip de discurs, care îndeamnă potențialul client la alegerea preparatului: „tocanâ di iepure fricos cumetrit cu bunătăți din grădinâ și maslini...îi tare bun. Zău aşa!", iar mușchiul de porc este prezentat într-o atmosferă de basm: „mușchiuleț di godac strochit cu zos fermecat și cumetrit cu barabuli zdroghiti și broccoli” în timp ce batalul necesită timp de „găteală”. Regiunile istorice românești se întâlnesc în meniu, deși totul ar fi trebuit să fie pur moldovenesc: 
„pastramă di batal juruită cu cârnăciori di Pleșcoi și malai pripit. La aiasta încearcă o şarbă românească de Garboiu”. Și pentru că orice narațiune are pe lângă personaje și dimensiunea cronologică, pe aceasta o regăsim ilustrată în „Mușchiuleț asprit în vin, tihnit cu zos de lămâie și mere coapte”, „Ciolan fumegăit la cuptior”, „Coaste descântate în afumătoare". La polul opus, unele dintre preparate au parte de o prezentare cât se poate de simplă, așa cum se întâlnește de obicei în meniuri: un substantiv însoțit de câțiva determinanți adjectivali sau complemente: „Pâiniță cu pătlăgele și busuioc”, „Tocinei rumeniți”, „Ciocolatâ șerbinti”, „Păstrăv la hârzob”.

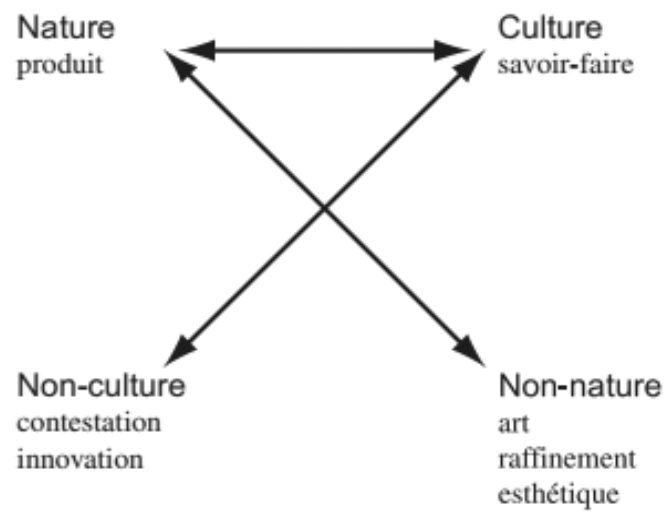

Figura 2: Axiologia meniului (Dupuy 2009b: 27)

\section{Stilistica meniului}

Amprenta stilistică a autorului și manipularea resurselor limbajului gastronomic creează identitatea stilistică a unui text culinar, identitate care este determinată de două situații distincte. Pe de o parte, avem termeni gastronomici care sunt înzestrați cu valori stilistice, iar pe de altă parte, sunt termenii gastronomici fără vreo valoare stilistică intrinsecă, dar pot influența profilul stilistic al textului (Șorcaru 2006: 21-23). Gastronomia, s-a spus, nu ar fi altceva decât arta asocierii ingredientelor diferite şi diverse într-o manieră menită să ne încânte papilele gustative și, în acest sens, ca în multe alte domenii de activitate și aici se uzează de figuri de limbaj, de metafore în ceea ce înseamnă contractul de comunicare cu clientul pe care îl creditezi apelând la competența sa lingvistică, în special cea idiomatică și expresivă. Fără a avea pretenția unei analize exhaustive, supunem atenției câteva aspecte regăsite în meniul de la $C M$.

De la prima pagină, atrage atenția dimensiunea ludică a textului. $\mathrm{Nu}$ știm cine este autorul/autorii acestui text, însă clientul este provocat la un joc de-a v-ați ascunselea printre cuvinte care se doresc a fi descifrate. Dupuy (2009b: 20) observă că există o legătură culturală bine stabilită între pretențiile gastronomice și folosirea „arsenalului" retoricesc, iar pentru consumator acestea sunt acceptabile numai atunci când se primește și un plus de valoare gastronomică. 
V.1. Dintre figurile stilistice înregistrate în prezentarea preparatelor culinare am evidenția comparații, epitete, metafore, hiperbolizări și metonimie. Atmosfera intimă de familie este reconstruită prin apelul la momente importante din viață: logodna, nunta sau botezul pe care le regăsim în personificări. Animalele a căror carne este ingredient principal al unor feluri de mâncare, din categoria „Găteli din vînat”, sunt caracterizate prin epitete și personificate. Astfel, iepurele fricos este „cumetrit cu bunătăți din grădină”, brânză cu smântână este „logodită cu mămăliguță”, „Bureții sunt nășiți cu ceapă”, batalul ,juruit cu cârnăciori”.

V.2. Epitetul simplu sau dublu caracterizator este figura centrală prin care autorul meniului prezintă oferta clienților. Iepurele este „fricos”, mușchiulețul „asprit...tihnit cu zos”, creierul „dosit” prin oușoare, ciolanul „fumegăit”, arichile „alintate”, tocineii „rumeniți” cașcavalul „tăvălit”, ceapa „zdroghită”, puiul „îndesat”, grădina „descântată”, chetre „calde”, bureți „jăruiți”, iar fileul este „un pește belit di pi oasâ”: „Somon belit di pi oasâ, făcut în cuptior”. Cafeaua este prezentată drept „fertură vătămătoare”. Conform definiției din dicționare, niciunul dintre sensurile pe care le are cuvântul nu se potrivește intenției cu care s-ar bea cafeaua la $C M$, întrucât nimeni nu-și dorește să se „vatăme”, ci mai degrabă să beneficieze de calitățile unei cafele bune. Varietățile de cafea sunt supuse și ele jocului lingvistic. Cunoscuta specialitate Espresso devine la CM o „cafea mică și chetroasă”, Capuccino e „Cafea amețâtâ cu lapti”, Ness frappé e transformat cu intenție ludică în „Cafea topchită cu lapte și țurțuri”, cafeaua neagră este „Cafea di ceea di-ți sare pălăria”, iar ceaiul este ironic denumit „zamă de buruieni aromate”.

V.3. Metafora culinară își face simțită prezența în cazul cotletelor de somon, crap, rechin, care aici se transformă în potcoave: „Potcoavi di somon cu zos de chiper roș”, „Potcoavi di rechin la tigaie (fără garniseală)”, „Potcoavi de crap în tigaie”.

V.4. Metonimia este ilustrată în meniul de la $C M$ când un preparat este denumit după un ingredient tipic care intră în compoziție: „Cotlet Valdostana”, „Chept numit de talieni Valdostana”, „Tocmagi di sâ cheamă Carbonara”, „Tocmagi Bolognesi”. Se respectă o rețetă și se promite o savoare bine cunoscută?

V.5. De asemenea, comparațile asociază produsul cu o anumită regiune sau tradiție culinară. Pe pagina cu „Găteli din Godac”, se pot citi denumiri precum:„Cotlet ca la curtea împăratului” (care împărat?), „Cotlet Valdostana ca la talieni” sau „Cotlet gătit ca la Mediterana” în care folosirea articolului hotărât „a” conferă dimensiunea hiperbolizată a preparatului propunând arhetipul, chintesența.

\section{Categorii onomastice}

Din punctul de vedere al onomasticii facem observaţia că în această categorie sunt incluse denumirile „pragmatice” (Munteanu Siserman 2013: 440), prezentate fie în funcție de modul (tehnica) de preparare sau a instrumentului folosit la prepararea acestuia, fie în funcție de efectele produse în urma consumării acestora, iar Dumitrăscel (2012: 10) remarcă faptul că, în cazul inventarului terminologic gastronomic, „românii au nume particulare, precise, mai ales pentru prima fază a prelucrării alimentelor de bază, reflectând trecerea de la natural la cultural, prin opoziția crud/ copt (sau fiert; 
viziunea lui Claude Lévi-Strauss din Le Cru et le Cuit)" (apud Munteanu Siserman 2013:431) lucru observabil și în textul supus analizei. Variatele tehnici folosite la prepararea diferitelor produse culinare se regăsesc, la nivel lingvistic, sub forma unui adjectiv de proveniență verbală, care surprinde maniera de coacere, fierbere, prăjire, afumare: „tocinei rumeniți”, „păstrăv la hârzob”, „Ciolan fumegăit la cuptior”, „Şunculițâ di casâ, fiartă-n moare”, mere coapte”.

Din aceeași perspectivă a categoriilor onomastice, denumirile preparatelor culinare din corpusul analizat, conform clasificării făcute de Munteanu Siserman (2013: 433), fac trimitere la cele două subdomenii majore ale onomasticii: antroponimia și toponimia. Prezența antroponimelor și a toponimelor în descrierea preparatelor, asocierea cu un teritoriu, cu o persoană sau o tradiție culinară conferă un plus de valoare și este o garanție a calității, a unui gust dorit: „Menestrel din Ceptura, făurar roșu ori Cabernet di la prințul Stirbey”. Însă, în cazul unor antroponime, numai o prealabilă cunoaștere a personajului poate edifica în privința calității și a gustului. Astfel, pentru un preparat de post, spanacul, intitulat „Foi di spanac cu malai di la Saveta” presupunem că Saveta este extrem de pricepută în a găti această mâncare. La fel ar trebui înțelese lucrurile și în cazul lui bunelu despre care s-ar ști că este și el foarte îndemânatic în arta culinară, deși tipul bunicului bucătar nu este model tipic culturii românești, mai ales în ceea ce privește un preparat care necesită timp de preparare, zacusca: „zacusca făcută di bunelu”.

Unele variante indigene redau ideea de comparație printr-o „construcție puternic toponimizată” (Felecan 2011: 67, apud Munteanu Siserman 435) alcătuită din nume generic + adverbul comparativ $c a+$ prepoziția la /în. Corpusul analizat prezintă și acest gen de denumiri:„Cotlet ca la curtea împăratului”, „Cotlet Valdostana ca la talieni”, „Cotlet gătit ca la Mediterana”, „salată ca la bulgăroi”.

\section{Concluzii}

Identitatea unui brand, indiferent dacă e gastronomic sau nu, se conturează prin mesajul și valorile transmise, în scopul influențării percepției consumatorilor. Atragerea clienților a aprins imaginația proprietarilor de restaurante și pensiuni, care au început să construiască noi strategii de marketing, mai mult sau mai puțin reușite. Intenția este aceea de a se poziționa cât mai bine în contextul competitiv actual, proiectând o imagine care să se imprime clar în percepția clienților. În acest sens, o nouă modă lansată în acest domeniu de activitate este, alături de meniurile cu o componentă vizuală foarte importantă, cea care exploatează resursele lingvistice pentru denumirea preparatelor.

În studiul de față, am subliniat rolul mijloacelor lingvistice creative în discursul gastronomic, oferind o ilustrare a acestora prin analiza meniului pensiunii/ restaurantului Casa Moldoveană din Piatra-Neamț. Chiar dacă prin numele restaurantului, prin decorul care este realizat în stil rustic, tradițional, exploatându-se astfel apetența consumatorului către gusturile de altădată, către mâncarea „ca la mama acasă”, modul de prezentare a ofertei culinare lasă de dorit. Nu este obligatoriu să ai un meniu în formă scrisă, dar, dacă alegi să faci acest lucru, atunci acesta trebuie scris corect în acord cu intenția vizată. Meniul de la Casa Moldoveană „reușește” să-i pună în față clientului, din 
punctul de vedere al prezentării meniului, „un bol cu salată”, un „ghiveci” lingvistic doar cu aromă moldovenească, gustul lăsând de dorit.

Considerăm că strategia de promovare a ofertei culinare aleasă în acest caz trădează neglijență lingvistică și poate crea suspiciuni în privința calității preparatelor oferite. În ciuda aparentei creativități lingvistice, consecința directă este aceea a afectării imaginii de brand, prin faptul că necunoașterea și nerespectarea normei literare și lingvistice duc la un amestec de stiluri greu „digerabil”.

\section{Acknowledgement}

This work was supported by a grant of the Romanian National Authority for Scientific Research and Innovation, CNCS/CCCDI - UEFISCDI, project number PN-III-P2-2.1-BG-2016-0390, within PNCDI III.

\section{Bibliografie}

Arvinte, V. 1995. Studiu lingvistic asupra primei cărți Facerea în Biblia de la Bucureşti 1688 (în comparație cu ms. 45 şi cu ms. 4389). În Monumenta Linguae Dacoromanorum. Iaşi: Editura Universității „Al. I. Cuza”.

Cazacu, M. 1997. Studiu introductiv la O lume într-o carte de bucate. Manuscris din epoca brâncovenească. București: Editura Fundației Culturale Române.

Dicționar explicativ ilustral al limbii române. 2007. Arc\&Gunivas.

Dobridor-Constantinescu, Gh. 1998. Dicționar de termeni lingvistici. București: Teora.

Drugă, L., P. Savin. 2009. The Cocktail of “Integrated” Menus. Ethnic Identity and Alterity in the Discourse of Menus. Philologica Jassyensia V (2): 111-117.

Dumistrăcel, S. 2006. Limbajul publicistic. Iași: Institutul European.

Dumistrăcel, S. 2008. Diminutive culinare. Ziarul Lumina, Iași, 13 august. http://ziarullumina. ro/diminutive-culinare-54659.html (accesat în august 2017).

Dupuy, J.-Ph. 2009a. Objet et prefiguration. L'exemple du menu de restaurant. http://www.meiinfo.com/wp-content/uploads/2014/02/MEI_3031_07.pdf (accesat iulie-august 2017).

Dupuy, J.-Ph. 2009b. Rhétorique du menu gastronomique. Communication \& langages: 19-33.

Felecan, D. 2011. Observații privitoare la configurația semiotică a unor nume de firme (NF) din spațiul public românesc actual”. În Limba română: ipostaze ale variației lingvistice. Actele celui de al 10-lea Colocviu al Catedrei de limba română, 3-4 decembrie 2010, vol. II, 63-76. Bucureşti: Editura Universității din Bucureşti.

Gheție, I. 1975. Baza dialectală a românei literare. Bucureşti: Editura Academiei.

Kapferer, J.-N. 2008. The New Strategiec Brand Management, 4th edition. London and Philadelphia: Kogan Page Limited.

Munteanu Siserman, M. 2013. Nume de preparate culinare autohtone în perspectiva globalizării (interpretări onomastice și socioculturale). http://www.diacronia.ro/ro/indexing/details/ A23392/pdf (accesat în septembrie 2017).

Savin, P. 2012. Universul din lingură. Despre terminologia alimentară românească. Iaşi: Institutul European.

Șorcaru, D. 2006. Stylistic Imprints and Marks of Identity. În Style and Language, Discourse and Literature, vol. IV, Horia Hulban (coord.), 21-23. Iași: Lumen.

http://www.pensiunipiatraneamt.ro/menu/ (accesat în 23 august 2017). 